\title{
Author Correction: Determinants of response and resistance to CD19 chimeric antigen receptor (CAR) T cell therapy of chronic lymphocytic leukemia
}

Joseph A. Fraietta, Simon F. Lacey, Elena J. Orlando, Iulian Pruteanu-Malinici, Mercy Gohil, Stefan Lundh, Alina C. Boesteanu, Yan Wang, Roddy S. O'Connor, Wei-Ting Hwang, Edward Pequignot, David E. Ambrose, Changfeng Zhang, Nicholas Wilcox, Felipe Bedoya, Corin Dorfmeier, Fang Chen, Lifeng Tian, Harit Parakandi, Minnal Gupta, Regina M. Young, F. Brad Johnson D, Irina Kulikovskaya, Li Liu, Jun Xu (D), Sadik H. Kassim, Megan M. Davis, Bruce L. Levine $\mathbb{0}$, Noelle V. Frey, Donald L. Siegel, Alexander C. Huang, E. John Wherry, Hans Bitter, Jennifer L. Brogdon, David L. Porter, Carl H. June $\mathbb{D}$ and J. Joseph Melenhorst

Correction to: Nature Medicine https://doi.org/10.1038/s41591-018-0010-1, published online 30 April 2018.

In the version of this article initially published, Fig. 4e was incorrect. The correct Fig. 4e is now provided. The error has been corrected in the HTML and PDF versions of the article.

e

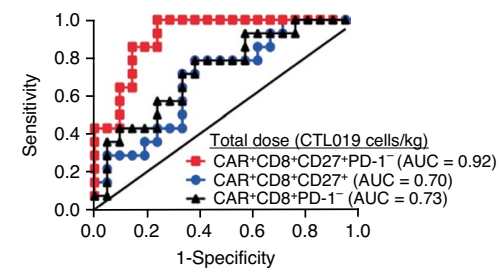

e

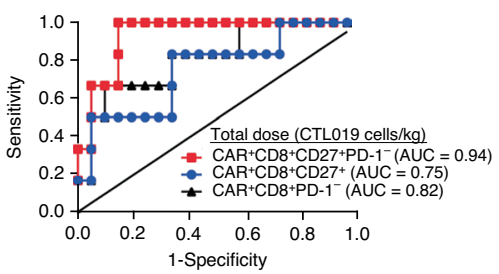

Fig. 4 | Original and Corrected.

Published online: 5 February 2021

https://doi.org/10.1038/s41591-021-01248-2

(c) The Author(s), under exclusive licence to Springer Nature America, Inc. 2021 